Article

\title{
Long-Term Monitoring of Different Field Traffic Management Practices in Cereals Production with Support of Satellite Images and Yield Data in Context of Climate Change
}

\author{
Vladimír Rataj ${ }^{1}$, Jitka Kumhálová ${ }^{2} \mathbb{D}$, Miroslav Macák ${ }^{1, * \mathbb{D}}$, Marek Barát ${ }^{1}$, Jana Galambošová ${ }^{1}$, Jan Chyba ${ }^{3} \mathbb{D}$ \\ and František Kumhála ${ }^{3}$ (D)
}

1 Institute of Agricultural Engineering, Transport and Bioenergetics, Faculty of Engineering, Slovak University of Agriculture in Nitra, Tr. A. Hlinku 2, 94976 Nitra, Slovakia; vladimir.rataj@uniag.sk (V.R.); marek.barat@uniag.sk (M.B.); jana.galambosova@uniag.sk (J.G.)

2 Department of Machinery Utilization, Faculty of Engineering, Czech University of Life Sciences Prague, Kamýcká 129, 16521 Prague, Czech Republic; kumhalova@tf.czu.cz

3 Department of Agricultural Machines, Faculty of Engineering, Czech University of Life Sciences Prague, Kamýcká 129, 16521 Prague, Czech Republic; chyba@tf.czu.cz (J.C.); kumhala@tf.czu.cz (F.K.)

* Correspondence: miroslav.macak@uniag.sk

Citation: Rataj, V.; Kumhálová, J.; Macák, M.; Barát, M.; Galambošová, J.; Chyba, J.; Kumhála, F. Long-Term Monitoring of Different Field Traffic Management Practices in Cereals Production with Support of Satellite Images and Yield Data in Context of Climate Change. Agronomy 2022, 12, 128. https://doi.org/10.3390/ agronomy 12010128

Academic Editors: Gabriele Cola and Yanbo Huang

Received: 22 November 2021

Accepted: 1 January 2022

Published: 5 January 2022

Publisher's Note: MDPI stays neutral with regard to jurisdictional claims in published maps and institutional affiliations.

Copyright: (C) 2022 by the authors. Licensee MDPI, Basel, Switzerland. This article is an open access article distributed under the terms and conditions of the Creative Commons Attribution (CC BY) license (https:// creativecommons.org/licenses/by/ $4.0 /)$.

\begin{abstract}
Cereals in Europe are mainly grown with intensive management. This often leads to the deterioration of the physical properties of the soil, especially increasing bulk density due to heavy machinery traffic, which causes excessive soil compaction. Controlled traffic farming (CTF) technology has the potential to address these issues, as it should be advantageous technology for growing cereals during climate change. The aim of this study was to compare the yield potential of CTF and standardly used random traffic farming (RTF) technology using yield maps obtained from combine harvester and satellite imagery as a remote sensing method. The experiment was performed on a 16-hectare experimental field with a CTF system established in 2009 (with conversion from a conventional (ploughing) to conservation tillage system). Yield was compared in years when small cereals were grown, a total of 7 years within a 13-year period (2009-2021). The results show that CTF technology was advantageous in dry years. Cereals grown in the years 2016, 2017 and 2019 had significantly higher yields under CTF technology. On the contrary, in years with higher precipitation, RTF technology had slightly better results-up to $4 \%$. This confirms higher productivity when using CTF technology in times of climate change.
\end{abstract}

Keywords: CTF technology; cereal cultivation; yield potential; remote sensing; climate change

\section{Introduction}

Wheat and barley are the most cultivated cereals worldwide [1]. The situation is similar in Slovakia, where wheat was grown on a total of 191,000 hectares and barley on a total of 131,000 hectares in 2020 [2]. Wheat is thus the most cultivated cereal in Slovakia followed by maize and barley.

Here, as well as in other countries (e.g., neighboring Bohemia), the vast majority of cereals are grown in the conditions of so-called "intensive agriculture", mainly in order to increase the productivity of cultivated crops [3]. For this reason, the weight and dimensions of agricultural machinery are also constantly increasing, and this development will continue to achieve increasing demand for technical performance and productivity [4]. According to Keller et al. [5], the wheel loads of combine harvesters have increased six times since 1960 and the wheel loads of tractors four times since 1955. In addition, wheel loads increase faster than the tire-soil contact area [6]. Both in the past and now, many published studies have shown a negative effect of soil compaction on soil structure and soil functions-e.g., [5,7-9]. Bluett et al. [9] also state that one of the main problems in mechanized crop production 
systems is that compaction reduces soil porosity, increases soil strength, impedes root exploration, reduces fertilizer and water use efficiency and increases the risks of soil water erosion. Soil compaction is also considered as one of the causes of the yield stagnation observed in many European countries [5].

Controlled traffic farming (CTF) technology, which protects most of the field cropped area by restricting all traffic to permanent traffic lanes, is a well-known but still underused solution to these problems $[9,10]$. This is possible by matching the track gauges of machinery and using highly accurate satellite navigation to keep the machinery at these traffic lines for all field operations. Various modifications of this technology suitable for practical application are known. In Australia, the track gauges of machinery are adjusted to 3 or $2 \mathrm{~m}$ (e.g., ([10-12]). Where this is not possible, the OutTrac or AdTrac modifications of this technology are used as compromises where the track gauges of the machines used are practically not adjusted (e.g., [10,13-16]). The implementation of CTF systems is easier together with the adoption of minimum- or zero-tillage technologies [10].

Moreover, Lemaire et al. [17] state that agricultural science must overcome an apparent contradiction between the necessity to improve agricultural systems' productivity and prevent degradation and restore the environment. Additionally, from this point of view, CTF technology is advantageous because it has, among other things, the potential to mitigate greenhouse gas emissions [3,18]. The motivation for the greater dissemination of CTF technology is also supported by studies focusing on the positive impact of this technology on crop yields and production economics [19-21].

The effort to increase or maintain stable yields and the economy of production is even more evident in the current climate change situation. According to the Working Group I contribution to the Fifth Assessment Report of the Intergovernmental Panel on Climate Change, global climate change is pointed out as the main reason for frequent variations in precipitation patterns [22]. There are many published studies which looked at the effect of soil compaction and precipitation on yield in different tillage technologies (e.g., $[21,23,24])$. Reduced soil tillage technologies seem to be advantageous from the point of view of a higher variation of precipitation, even though a lower yield is expected in the first years after conversion from tillage technologies with plough [25].

Modern methods of remote sensing can be used to assess the suitability of implemented tillage technologies. Remote sensing methods can be used to assess the historical development of crop vigor and yield potential. Remote sensing is a non-destructive method of surface sensing usable for sensing the properties of cereal crops [26-28]. Freely available remote sensing data in the visible spectrum can be achieved from the Landsat and Sentinel 2 satellite missions. Landsat satellite images can be used in a historical context because the individual satellite missions follow each other [29]. The Sentinel 2 satellite mission from the program Copernicus of the European Space Agency also follows on the Landsat satellite mission from the range-wavelength-spectrum-used point of view [30]. The problem may be moderate spatial resolution $(30 \mathrm{~m})$ and the subsequent generalization of information; however, Kumhálová et al. [31] used images from the Landsat satellite on an 11-hectare plot with to monitor grains good results (winter wheat and oat). The Normalized Difference Vegetation Index (NDVI), which is ranked among the most popular vegetation indices (e.g., [32-34]), can be calculated from the data obtained from both of these satellite missions. The NDVI calculation is based on the reflectance ratio in the red and near-infrared bands, e.g., as in [35].

As this literature review suggests, CTF technology can be advantageous as a technology that improves the physical properties of soil with a positive effect on yields even in times of global climate change, and these effects can be assessed using satellite imagery.

The main aim of this study, therefore, is a multiannual comparison of crop vigor and soil/yield potential in cereal production at areas farmed under CTF and RTF technology with soil conservation tillage. This comparison was made in an experimental field for years with different courses of precipitation in the growing season of cereals using satellite imagery with the support of yield maps when available. The scientific hypothesis which 
this work tries to answer is that CTF technology is an advantageous technology for growing cereals in times of climate change and brings yield stability even in dry years.

\section{Materials and Methods}

\subsection{Field Management}

To be able to evaluate the differences between the two traffic management systems, the university farm of the Slovak University of Agriculture in Kolinany, Slovakia was selected. The management of the 16-hectare experimental field "Pri Jeleneckej ceste" $\left(48^{\circ} 22^{\prime} 16.97^{\prime \prime} \mathrm{N}\right.$, $18^{\circ} 12^{\prime} 25.43^{\prime \prime}$ E) was converted into controlled traffic farming (CTF) in 2009. (Figure 1). Based on the soil classification with the BPEJ units, soil at the experimental field is classified as loamy soil [36].

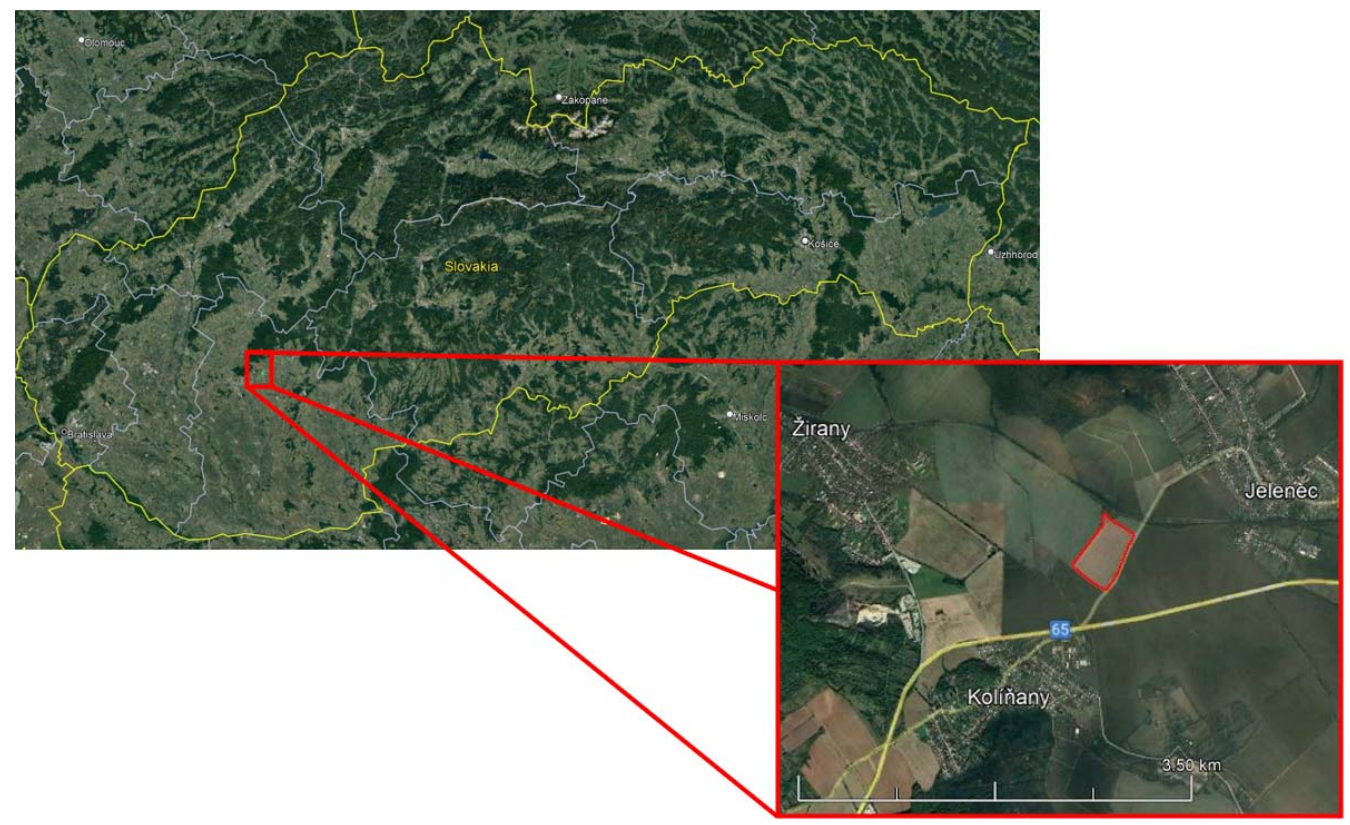

Figure 1. Study site of CTF experimental field "Pri Jeleneckej ceste" in Kolínany-Slovakia.

The elevation data were bought from Eurosense and processed to the digital elevation model (DEM), slope model and topography wetness model (TWI) in ArcGIS Pro version 2.8.3 and QGIS version 3.16 SWs according to the methodology described in $[31,37,38]$. The DEM showed that the field elevation was between 196 and $212 \mathrm{~m}$ above sea level (a.s.l.). The field exhibited a downward slope from east to west, which ranged between $3 \%$ and $7 \%$.

The experimental field was converted from the traditional RTF system into CTF in 2009 (intensive tillage with ploughing was converted to the minimum-conversation tillage system too). An "OutTrac" CTF system with 6m module [39] was implemented-Layout of machinery traffic is provided in Figure 2. The OutTrac CTF system uses two track gauges on the same centerline. One gauge matches the common standard on tractors and implements used, and the other matches the combine harvester used.

This enabled the use of machinery available on the farm without the need for modification, which therefore had no impact on the costs associated with the experimental design. This approach was also chosen to represent a "low cost of conversion" scenario likely to be adopted by growers in Central Europe. This traffic system results in $36.2 \%$ (see Figure 2) of the area tracked. Details on the experiment layout can be found in the work of Galambošová et al. (2017) [15]. 


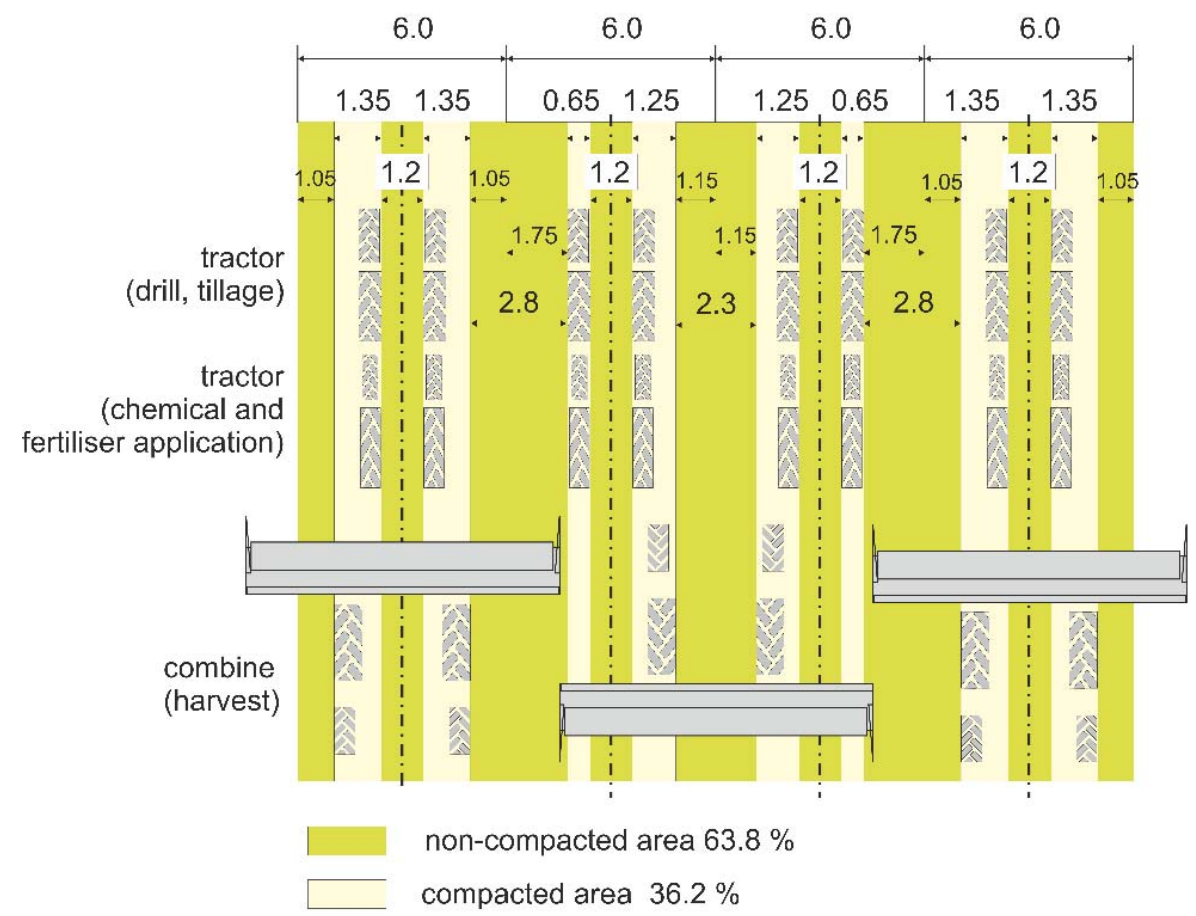

Figure 2. Tramlines (size in meters) of used machines without adaptation of track width (CTFexperimental field in Kolinany).

In order to simulate the RTF system on the same field, the three band areas were introduced in 2010, according to the real conditions in practice (proportion of field traffic intensity in the RTF system-as states Kroulík et al. [40]). These advisedly created areas (named as RTF strips, Figure 3) represent the RTF system with machine-introduced compaction. These 25-meter-wide strips (whose areas vary from 0.8 to $0.85 \mathrm{ha}$ ) are created by the wheel-by-wheel traffic of tractor JD 8230 with the RTK guidance system (tractor weight $9673 \mathrm{~kg}$; inflation pressure of tires 2.0 bar) at a right angle to the direction of CTF lines, once pre year, after harvest and annually from 2010.

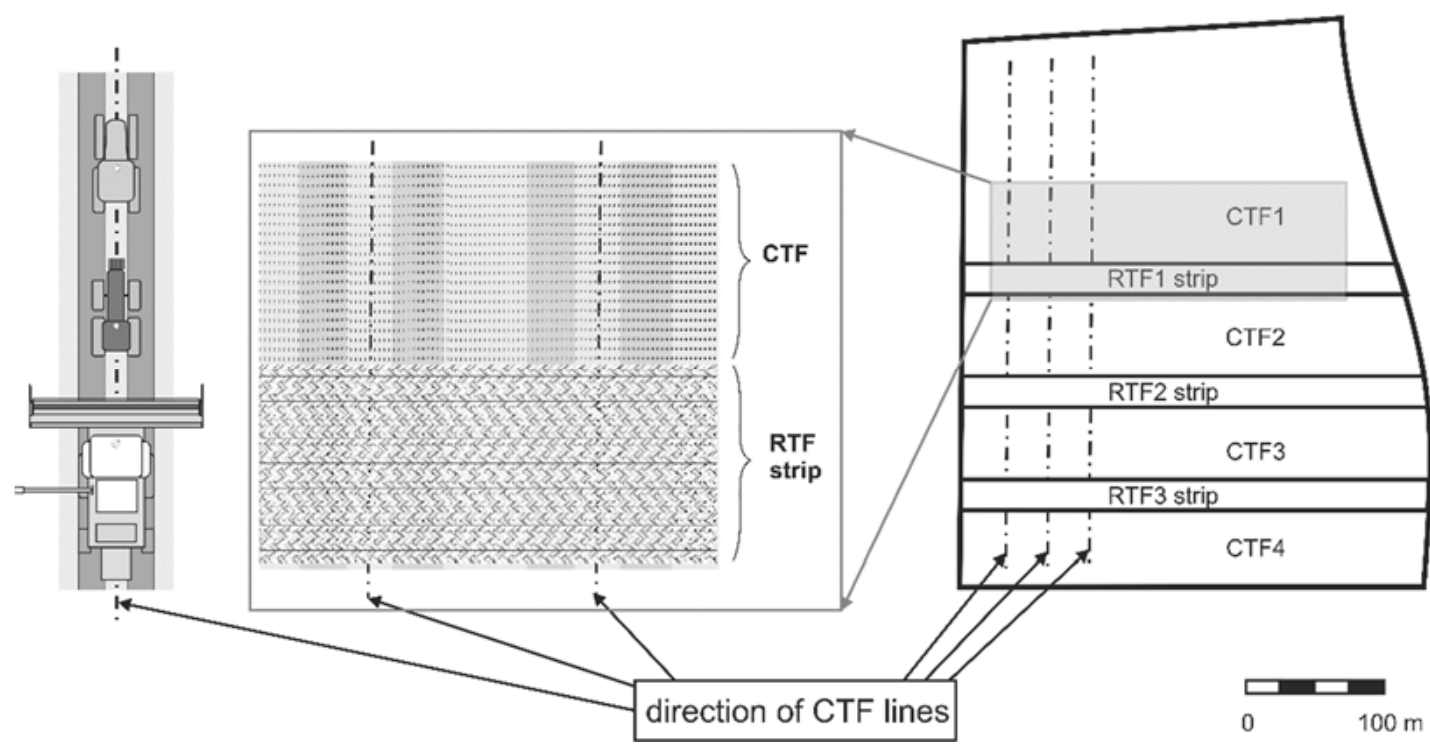

Figure 3. Pattern of experimental field (areas of CTF system: CTF1, CTF2, CTF3, CTF4; and areas of RTF system = RTF strips labeled as RTF1, RTF2, RTF3). 
Considering the main requirement of the CTF [41] to be combined with conservation tillage technologies, shallow tillage has been used at the field since the 2009. The last deep-tillage operation was conducted using a subsoiler at a 350-millimeter working depth in the previous autumn of 2008. This was performed to remove compaction in the upper part of the soil profile. Details on machinery used for operations at the experimental field are provided in Table 1.

Table 1. Overview of machineries used for field operations.

\begin{tabular}{|c|c|c|}
\hline Operation & Tractor & Machine Implement \\
\hline $\begin{array}{l}\text { Seedbed preparation } \\
\text { Stubble tillage }\end{array}$ & John Deere 8230 & Lemken Rubin 6 m, disc harrow \\
\hline Sowing & John Deere 8100 & Lemken Solitair 6 m, seeder \\
\hline $\begin{array}{l}\text { Chemicals/fertilizer } \\
\text { application }\end{array}$ & NH T6070 & $\begin{array}{l}\text { Agio NAPA, } 24 \mathrm{~m} \text {, sprayer/Amazone ZA m 1500, } \\
24 \mathrm{~m} \text {, spreader. }\end{array}$ \\
\hline Harvest & \multicolumn{2}{|c|}{$\begin{array}{l}\text { Claas Lexion } 480 \text { and } 600 \text {, John Deere } 760 \text {; both with yield } \\
\text { monitoring system }\end{array}$} \\
\hline
\end{tabular}

\subsection{Crop Rotation and Climate Conditions}

For solving defined hypothesis, only the cereals growing seasons were selected. Information about crops and satellite images are in Table 2. In 2009, the yield was not measured during the harvest by yield monitoring system at combined harvester, only data from farmer's records are available - this is weighted harvested mass. Therefore, the standard deviation is not available for this year. Crops and varieties were selected by the agronomist based on the farmer's best practice. Only the years, which are concretely compared in Results and Discussion section, were taken into account (since 2009).

Table 2. Overview of satellite images with information about crops (crop, variety, sowing date, harvest date and average yield in $\mathrm{t} \cdot \mathrm{ha}^{-1}$ with standard deviation).

\begin{tabular}{ccccccc}
\hline $\begin{array}{c}\text { Date of Satellite } \\
\text { Images }\end{array}$ & $\begin{array}{c}\text { Satellite } \\
\text { Platform }\end{array}$ & Crop & Sowing Date & Harvest Date & $\begin{array}{c}\text { Average Yield } \\
\left(\mathbf{t} \cdot \mathbf{h a} \mathbf{a}^{-\mathbf{1})}\right.\end{array}$ & $\begin{array}{c}\text { St. Dev.-Yield } \\
\left(\mathbf{t} \cdot \mathbf{h a} \mathbf{-}^{-1}\right)\end{array}$ \\
\hline 16 June 2009 & L5 TM & Spring barley cv. Kango & 27 March 2009 & 23 July 2009 & 5.0 & - \\
22 June 2011 & L5 TM & Winter wheat cv. Augustus & 22 October 2010 & 16 July 2011 & 6.2 & 1.7 \\
23 June 2014 & L8 OLI & Spring barley cv. Kango & 6 March 2014 & 11 July 2014 & 4.8 & 0.9 \\
19 June 2016 & L8 OLI & Winter wheat cv. HYFI & 13 October 2015 & 12 July 2016 & 7.9 & 1.6 \\
30 May 2017 & L8 OLI & Winter barley cv. Wintmalt & 30 September 2016 & 26 June 2017 & 6.7 & 1.5 \\
12 June 2019 & S2 MSI & Winter wheat cv. RGT Reform & 3 October 2018 & 16 July 2019 & 7.8 & 1.2 \\
16 June 2021 & S2 MSI & Spring barley cv. IS Maltigo & 11 March 2021 & 20 July 2021 & 3.0 & 1.2 \\
\hline
\end{tabular}

L5 TM—Landsat 5 Thematic Mapper; L8 OLI—Landsat 8 Operational Land Imager; S2 MSI—Sentinel 2 Multispectral Instrument.

Monthly average precipitation throughout the assessed period (2009-2021) focused on the main vegetation season (March-July) is displayed in Figure 4. Data were obtained from the meteorological station situated in the university farm, Kolinany, and from the Slovak Hydrometeorological Institute [42]. 


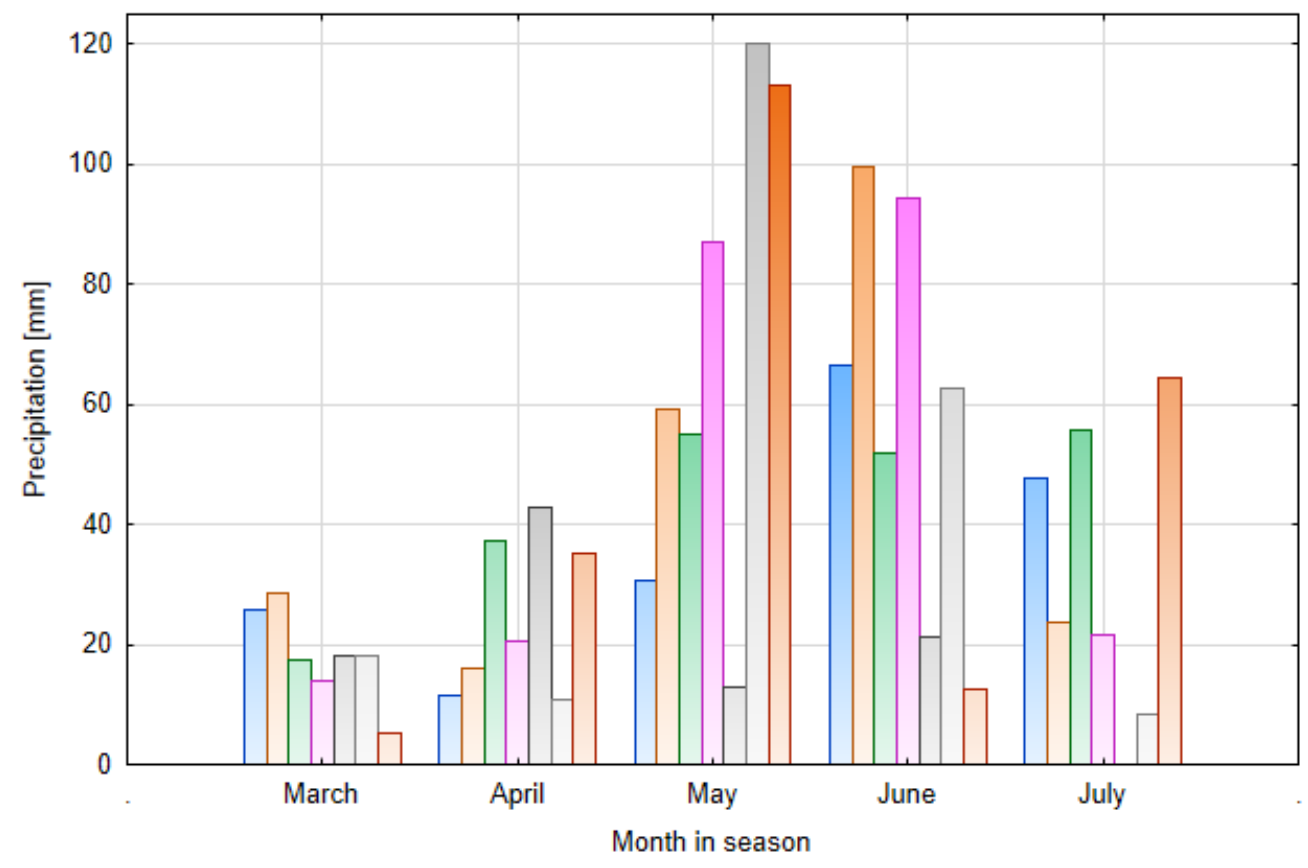

2009 spring barley, $\square 2011$ winter wheat, $\square 2014$ spring barley, $\square 2016$ winter wheat, 2017 winter barley, $\square 2019$ winter wheat, $\square 2021$ spring barley

Figure 4. Monthly average precipitation throughout the assessed period of time (2009-2021) focused on the main vegetation season (March-July).

\subsection{Satellite and Yield Data}

The experimental field was monitored from 2009 onwards by satellite images. Only images related to selected years with barley and wheat were processed and analyzed. The overview of selected satellite images is given in Table 2. The images were downloaded from the USGS archive (https:/ / earthexplorer.usgs.gov/; access date: 30 November 2021) and Open Access Hub of the ESA Copernicus program (https: / / scihub.copernicus.eu/dhu s/\#/home; accessed on: 30 November 2021) in L2 format (with atmospheric correction). Normalized Difference Vegetation Index (NDVI) was calculated for each of these images in ENVI 5.6.1 SW [43] and SNAP 8.0.7 SW [44].

Yield was measured by combine harvesters equipped with yield monitor from 2011, 2014, 2016, 2017, 2019 and 2021. CLAAS Combine harvesters with optical yield sensor (DGPS precision of spatial position) were used in all seasons with exception of the year 2019, when a John Deere combine harvester with impact force yield sensor (RTK precision of spatial position) was contracted to measure the yield variability.

Yield data were processed using ArcGIS Pro 2.8.3 SW [45] by common geostatistical methodology (detail in [46]) on the resulting kriging maps. Because two crops (wheat and barley) were taken into account, yield and NDVI were converted to the relative values, and frequency maps were calculated. The frequency maps (FM) of both yield and NDVI were created with the help of the Cell Statistics tool by setting the maximum values of pixels. The calculation of relative yield and NDVI values was based on the ratio of individual pixel values and average value of the plot multiplied by 100 to be expressed in relative values $(\%)$. The resulting maps could then show places with potential maximum vigor in the case of NDVI and yield in the case of yield maps.

The statistical analysis of data sets was processed in software TIBCO Statistica ver. 13.5.0.17 (software developed by TIBCO Software Inc., Tulsa, OK, USA). It was a mainly statistical analysis, which specifically used the ANOVA tool and Tukey's HSD (honestly significant difference) test at the significance level 0.05. 


\section{Results}

As was proposed in the methodology, in order to compare CTF and RTF technology during the 6 years, yield and NDVI values were determined for the monitored locations. The summary statistics of resulting relative yield, relative NDVI expressed in percent for selected years (since 2009) and individual types of management (CTF and RTF) are given in Table 3. The summary statistics of resulting frequency maps for NDVI, yield and topography wetness index and individual types of management system (CTF and RTF) are reported in Table 4.

Table 3. Summary statistics of resulting relative yield in $\%$ and relative NDVI (N) in \% for selected years $(\mathrm{Y})$ and individual types of traffic management (Var). Tukey HSD test of homogenous groups $[1,2, \ldots], \alpha=0.05$.

\begin{tabular}{|c|c|c|c|c|c|c|c|c|c|c|c|}
\hline \multirow{2}{*}{ Year } & \multirow{2}{*}{ Var } & \multicolumn{2}{|c|}{ Mean } & \multicolumn{2}{|c|}{ Median } & \multicolumn{2}{|c|}{ St. Dev. } & \multicolumn{2}{|c|}{ Max } & \multicolumn{2}{|c|}{ Max-Min } \\
\hline & & Yield & $\mathbf{N}$ & Yield & $\mathbf{N}$ & Yield & $\mathbf{N}$ & Yield & $\mathbf{N}$ & Yield & $\mathbf{N}$ \\
\hline \multirow{7}{*}{2009} & CTF1 [6-12] & - & 101.8 & - & 100.4 & - & 6.7 & - & 118.7 & - & 35.3 \\
\hline & CTF2 [3-8] & - & 101.4 & - & 100.2 & - & 6.1 & - & 119.1 & - & 35.7 \\
\hline & CTF3 $[3-8,10]$ & - & 101.2 & - & 100.1 & - & 5.8 & - & 117.2 & - & 33.8 \\
\hline & CTF4 [2-7] & - & 101.0 & - & 100.1 & - & 5.8 & - & 118.3 & - & 37.1 \\
\hline & RTF1 [3-13] & - & 101.0 & - & 99.9 & - & 5.7 & - & 116.9 & - & 35.2 \\
\hline & RTF2 [2-12] & - & 101.0 & - & 99.9 & - & 5.7 & - & 117.9 & - & 36.9 \\
\hline & RTF3 [2-11] & - & 100.9 & - & 101.3 & - & 5.7 & - & 118.5 & - & 37.3 \\
\hline \multirow{7}{*}{2011} & CTF1 [2-4] & 90.0 & 99.3 & 89.4 & 98.0 & 16.5 & 13.7 & 135.8 & 127.4 & 81.9 & 58.8 \\
\hline & CTF2 [4-12] & 94.0 & 99.8 & 94.9 & 98.0 & 18.1 & 12.8 & 148.1 & 133.5 & 87.1 & 62.3 \\
\hline & CTF3 [8-16] & 96.7 & 100.7 & 99.3 & 98.0 & 17.5 & 12.3 & 149.1 & 134.9 & 89.3 & 63.7 \\
\hline & CTF4 $[9,12-16]$ & 97.6 & 101.1 & 99.5 & 98.7 & 17.4 & 12.2 & 144.9 & 127.4 & 91.0 & 59.2 \\
\hline & RTF1 [2-13] & 97.9 & 101.1 & 99.6 & 98.7 & 17.4 & 12.0 & 145.7 & 128.1 & 88.5 & 59.9 \\
\hline & RTF2 [3-15] & 98.4 & 101.1 & 99.9 & 98.7 & 17.4 & 11.9 & 146.8 & 127.2 & 88.9 & 57.5 \\
\hline & RTF3 [12-16] & 99.0 & 101.3 & 100.2 & 98.7 & 17.4 & 11.8 & 145.1 & 127.8 & 90.8 & 58.6 \\
\hline \multirow{7}{*}{2014} & CTF1 $[2,3]$ & 91.9 & 98.3 & 91.4 & 99.3 & 15.2 & 7.3 & 141.2 & 113.1 & 85.4 & 33.0 \\
\hline & CTF2 [7-13,15] & 95.4 & 99.4 & 97.5 & 101.4 & 15.1 & 7.0 & 145.3 & 112.9 & 89.5 & 33.5 \\
\hline & CTF3 [16] & 98.1 & 101.0 & 100.2 & 102.8 & 15.1 & 7.3 & 144.9 & 117.8 & 88.7 & 37.7 \\
\hline & CTF4 [7-16] & 98.0 & 101.2 & 99.7 & 102.9 & 15.4 & 7.1 & 149.4 & 119.7 & 93.6 & 36.9 \\
\hline & RTF1 [2-8] & 98.1 & 101.1 & 99.7 & 102.7 & 15.2 & 7.1 & 150.1 & 118.7 & 94.4 & 38.1 \\
\hline & RTF2 [13-16] & 98.6 & 101.4 & 100.5 & 102.9 & 15.0 & 7.0 & 151.2 & 118.2 & 93.8 & 37.1 \\
\hline & RTF3 [9,11-16] & 98.7 & 101.6 & 100.4 & 103.0 & 15.0 & 7.0 & 151.7 & 119.0 & 93.9 & 37.9 \\
\hline \multirow{7}{*}{2016} & CTF1 [6-12] & 101.1 & 101.8 & 103.3 & 100.9 & 19.1 & 4.5 & 143.1 & 114.9 & 141.6 & 26.9 \\
\hline & CTF2 [2-5] & 101.0 & 101.1 & 103.3 & 100.6 & 19.0 & 4.2 & 139.9 & 114.7 & 138.4 & 27.1 \\
\hline & CTF3 [2-4] & 101.1 & 100.6 & 103.3 & 100.3 & 19.1 & 4.1 & 141.9 & 115.4 & 140.5 & 27.3 \\
\hline & CTF4 [2-4] & 100.8 & 100.3 & 103.2 & 100.0 & 18.9 & 4.1 & 136.6 & 114.7 & 135.2 & 28.8 \\
\hline & RTF1 [2-12] & 100.8 & 100.3 & 103.2 & 100.1 & 18.9 & 4.0 & 135.0 & 116.1 & 133.6 & 29.1 \\
\hline & RTF2 $[2,-6]$ & 101.0 & 100.2 & 103.3 & 99.9 & 19.1 & 4.0 & 141.6 & 113.8 & 140.2 & 29.9 \\
\hline & RTF3 [2-8] & 100.5 & 100.1 & 103.0 & 99.9 & 18.7 & 4.0 & 132.0 & 114.5 & 130.5 & 30.1 \\
\hline \multirow{7}{*}{2017} & CTF1 [5-12] & 105.3 & 101.4 & 107.8 & 101.5 & 10.9 & 2.2 & 122.9 & 106.0 & 64.9 & 15.4 \\
\hline & CTF2 [2-7] & 105.5 & 101.0 & 107.4 & 101.0 & 10.4 & 2.3 & 123.2 & 105.9 & 65.1 & 15.7 \\
\hline & CTF3 [3-7] & 105.8 & 100.8 & 107.1 & 100.8 & 10.3 & 2.3 & 127.1 & 106.3 & 69.1 & 24.0 \\
\hline & CTF4 [2-4] & 104.8 & 100.5 & 106.2 & 100.6 & 10.9 & 2.4 & 126.9 & 105.7 & 68.8 & 25.1 \\
\hline & RTF1 [2-8] & 104.7 & 100.4 & 106.3 & 100.5 & 11.0 & 2.4 & 128.0 & 104.9 & 69.3 & 23.9 \\
\hline & RTF2 [2-8,10-12] & 104.8 & 100.4 & 106.4 & 100.5 & 10.9 & 2.5 & 127.3 & 107.0 & 65.7 & 25.0 \\
\hline & RTF3 [2-11] & 104.9 & 100.3 & 106.3 & 100.4 & 10.8 & 2.4 & 127.5 & 105.8 & 69.5 & 24.1 \\
\hline \multirow{7}{*}{2019} & CTF1 [5-12] & 104.5 & 101.0 & 105.1 & 101.4 & 12.7 & 1.8 & 157.4 & 103.7 & 116.3 & 14.7 \\
\hline & CTF2 [2-4] & 103.7 & 100.5 & 104.4 & 101.2 & 13.1 & 3.4 & 158.3 & 104.1 & 117.7 & 35.3 \\
\hline & CTF3 [2-6] & 102.8 & 100.4 & 103.5 & 101.3 & 13.2 & 4.0 & 155.1 & 103.5 & 118.1 & 36.1 \\
\hline & CTF4 [2-8] & 101.9 & 100.5 & 102.8 & 101.4 & 13.3 & 3.8 & 158.0 & 104.2 & 123.8 & 35.8 \\
\hline & RTF1 [2-7] & 101.9 & 100.5 & 102.7 & 101.3 & 13.3 & 3.7 & 157.6 & 103.9 & 123.1 & 35.1 \\
\hline & RTF2 [2-7] & 101.9 & 100.4 & 102.8 & 101.3 & 13.3 & 3.8 & 155.9 & 105.0 & 122.9 & 37.2 \\
\hline & RTF3 [2-13] & 101.8 & 100.5 & 102.7 & 101.4 & 13.2 & 3.8 & 158.3 & 104.6 & 123.5 & 34.9 \\
\hline
\end{tabular}


Table 3. Cont.

\begin{tabular}{|c|c|c|c|c|c|c|c|c|c|c|c|}
\hline \multirow{2}{*}{ Year } & \multirow{2}{*}{ Var } & \multicolumn{2}{|c|}{ Mean } & \multicolumn{2}{|c|}{ Median } & \multicolumn{2}{|c|}{ St. Dev. } & \multicolumn{2}{|c|}{ Max } & \multicolumn{2}{|c|}{ Max-Min } \\
\hline & & Yield & $\mathbf{N}$ & Yield & $\mathbf{N}$ & Yield & $\mathbf{N}$ & Yield & $\mathbf{N}$ & Yield & $\mathbf{N}$ \\
\hline \multirow{7}{*}{2021} & CTF1 [1] & 93.8 & 93.4 & 93.0 & 93.5 & 34.0 & 21.2 & 175.9 & 135.8 & 176.2 & 98.4 \\
\hline & CTF2 [5-13] & 97.5 & 95.8 & 96.6 & 96.4 & 34.4 & 21.1 & 198.1 & 141.4 & 198.4 & 104.0 \\
\hline & CTF3 $[14,16]$ & 102.7 & 98.3 & 99.3 & 97.7 & 35.5 & 20.8 & 203.1 & 139.9 & 203.4 & 103.9 \\
\hline & CTF4 [14-16] & 102.7 & 99.4 & 99.9 & 99.3 & 35.4 & 20.7 & 202.9 & 142.1 & 202.9 & 104.2 \\
\hline & RTF1 [1,2] & 102.0 & 99.1 & 98.9 & 98.8 & 35.7 & 20.7 & 203.5 & 140.9 & 204.0 & 107.0 \\
\hline & RTF2 [9-16] & 102.5 & 99.4 & 99.3 & 98.9 & 35.9 & 20.7 & 200.9 & 141.2 & 203.6 & 106.5 \\
\hline & RTF3 [8-16] & 103.1 & 99.7 & 99.8 & 98.9 & 35.8 & 20.5 & 204.0 & 143.1 & 202.8 & 108.1 \\
\hline
\end{tabular}

CTF-Controlled Traffic Farming; RTF-Random Traffic Farming; St. Dev.-Standard Deviation.

Table 4. Summary statistics of resulting frequency maps (FM) for NDVI, yield and topography wetness index (TWI) and individual types of management system: controlled traffic farming (CTF) and random traffic farming $(\mathrm{RTF})$.

\begin{tabular}{|c|c|c|c|c|c|c|c|c|c|c|c|c|}
\hline Parameter & FM NDVI & FM Yield & TWI & FM NDVI & FM Yield & TWI & FM NDVI & FM Yield & TWI & FM NDVI & FM Yield & TWI \\
\hline & \multicolumn{3}{|c|}{ CTF1 } & \multicolumn{3}{|c|}{ CTF2 } & \multicolumn{3}{|c|}{ CTF3 } & \multicolumn{3}{|c|}{ CTF4 } \\
\hline Mean & 110.0 & 118.1 & 4.6 & 110.0 & 119.1 & 4.6 & 110.7 & 121.4 & 4.7 & 110.9 & 121.2 & 4.9 \\
\hline Median & 107.2 & 114.4 & 4.7 & 106.7 & 114.6 & 4.6 & 106.9 & 114.9 & 4.7 & 107.2 & 115.1 & 4.8 \\
\hline St. Dev. & 8.9 & 15.6 & 1.1 & 9.4 & 17.1 & 1.0 & 10.3 & 20.1 & 1.1 & 10.3 & 20.2 & 1.2 \\
\hline Max & 138.2 & 179.5 & 7.2 & 138.2 & 198.1 & 7.2 & 140.5 & 203.1 & 7.2 & 140.5 & 203.1 & 7.6 \\
\hline \multirow[t]{2}{*}{ Max-Min } & 40.4 & 93.3 & 5.8 & 40.4 & 111.9 & 5.8 & 42.7 & 116.9 & 5.8 & 42.7 & 126.7 & 6.2 \\
\hline & & RTF1 & & & RTF2 & & & RTF3 & & & & \\
\hline Mean & 110.7 & 121.0 & 4.8 & 110.8 & 121.3 & 4.8 & 110.9 & 121.5 & 4.8 & & & \\
\hline Median & 106.9 & 114.9 & 4.7 & 106.9 & 115.0 & 4.7 & 107.1 & 115.1 & 4.7 & & & \\
\hline St. Dev. & 10.4 & 20.1 & 1.2 & 10.5 & 20.3 & 1.2 & 10.6 & 20.5 & 1.2 & & & \\
\hline Max & 140.5 & 203.1 & 7.6 & 140.5 & 203.1 & 7.6 & 140.5 & 203.1 & 7.6 & & & \\
\hline Max-Min & 42.7 & 126.7 & 6.2 & 42.7 & 126.7 & 6.2 & 42.7 & 126.7 & 6.2 & & & \\
\hline
\end{tabular}

As a first monitored crop, spring barley, middle-late variety Kangoo with a high lodging resistant, was grown in the experimental field in 2009. The results describe a situation before the three band strips were established. The yield data are available only as an average weighted value for the whole plot, not for the combine harvester. The crops were evaluated only by NDVI from the latest Landsat 5 image, when the crop was green (16 June) in the growth stage "development of grains" (see Table 2). The weighted yield reached $5.0 \mathrm{t} \cdot \mathrm{ha}^{-1}$, the highest yield from the overview of spring barley.

As a third crop after CTF introduction to the field, winter wheat of the variety Augustus was grown in 2010/2011. The yield data were measured by the yield sensor of the combine harvester used. The crops were also evaluated by NDVI from Landsat 5 taken on 22 June, when the crop was in the growth stage related to the "development of grains" (Table 2). The measured yield of $6.2 \mathrm{t} \cdot \mathrm{ha}^{-1}$ was the lowest for winter wheat crop during the selected years. Nevertheless, the standard deviation $\left(1.7 \mathrm{t} \cdot \mathrm{ha}^{-1}\right)$ was the highest in comparison with other years.

Cereal production was also assessed for the year 2014. Here, spring barley, of the middle-late variety Kangoo was grown. The yield measured by the yield sensor of the combine harvester was relatively low in comparison with other years with the same crop; the weighted yield reached the average value of $4.8 \mathrm{t} \cdot \mathrm{ha}^{-1}$. The stand of the crop was evaluated by NDVI from Landsat 8 acquired on 22 May that related to the growth stage of heading.

Cereals were grown at the experimental field again in 2016. In this season, winter wheat, of the early variety Hyfi, was grown. The measured yield had the highest values $\left(7.9 \mathrm{t} \cdot \mathrm{ha}^{-1}\right)$ in comparison with other years with winter wheat. Nevertheless, the experimental field was evaluated by NDVI from Landsat 8 image acquired on 19 June (growth stage "development of grains"). 
The following year, 2017, winter barley, of the middle-late variety Wintmalt, was grown. The measured yield reached values of $6.7 \mathrm{t} \cdot \mathrm{ha}^{-1}$ with average standard deviation $\left(1.5 \mathrm{t} \cdot \mathrm{ha}^{-1}\right)$ in comparison with other years. The field was evaluated by NDVI from Landsat 8 image acquired on 30 May during the flowering growth stage.

In the 2019 winter wheat, of the late variety RGT Reform, was grown. In the 2019, the measured yield was on average $7.8 \mathrm{t} \cdot \mathrm{ha}^{-1}$ with the lowest standard deviation of $1.2 \mathrm{t} \cdot \mathrm{ha}^{-1}$ in comparison with other years with winter wheat. The NDVI image was taken on June 12 from Sentinel 2 during the flowering growth stage.

The last assessed crop, spring barley, of the variety Maltigo, with a high resistance to lodging and drought, was grown in 2021. NDVI was calculated from a Sentinel 2 image acquired on 16 June in the growth stage "development of grains". The measured resulting yield was then only $3.04 \mathrm{t} \cdot \mathrm{ha}^{-1}$ with the same standard deviation as in previous year, $1.2 \mathrm{t} \cdot \mathrm{ha}^{-1}$.

\section{Discussion}

This study discusses the effect of CTF technology (in this study referred to as CTF areas) compared with RTF technology, which is practically field traffic-conducted randomly on the whole field area (referred as RTF strips). This was able to be accomplished due to the fact that a field-scale experiment with CTF technology implemented on the whole field was used. To show the differences with random traffic, three strips run across the CTF traffic lines were annually compacted. This layout perfectly enabled us to see the differences between the two technologies compared for one field with specific soil, water and climate conditions. This study shows results from six growing seasons with cereals production. So, the effect of climate and season is shown as well. As the final yield was affected by all the yield factors, weather/water conditions are first discussed in the text.

The highest yield value in 2009 was probably a response to a rainy June. Nevertheless, April and May, during the growth stage tillering and stem elongation, performed very poorly in terms of precipitation (see Figure 4). This could lead to higher relative mean and median NDVI values in CTF areas than in the RTF strips, except for area RTF3, where the value was lower because of a higher TWI value (see Tables 3 and 4). These relative NDVI values are the result of the state of the stand at the end of a rainy June. The stand seemed vital but was affected by limited growth in previous growth stages. One of the characteristics of this variety is its moderate ability to tillering, especially in worse growth conditions. On the other hand, the wetter RTF3 plots showed an excess of water and a decrease in NDVI values in the soil with compaction caused by machinery. These statements are in agreement with Kuznetsova et al. (2009) [47], which describes that the higher and longer the pressure exerted on the soil surface with the degree of soil moistening was, the higher the soil compaction and decreasing yield values. Lipiec et al. (2003) [48] mentions that moderately compacted soil could lead to increasing the crop yield; nevertheless, the yield then decreases with further soil compaction. It especially depends on variables such as initial soil compactness, weather and soil type. CTF areas had higher relative values and a lower difference between the maximum and minimum than the RTF strips, indicating higher variability.

The low relative and measured yields in 2011 with relatively high standard deviation were probably the result of a dry April during crop tillering and unfortunately was not affected by the average precipitation in May and the high total precipitation in June. The Augustus variety unfortunately has a moderate lodging resistance and moderate resistivity to powdery mildew, rust fungus and fusarium, which usually develop during wet conditions. CTF areas had lower relative values of NDVI than RTF areas. Standard deviation of yield and NDVI in CTF areas were significantly higher than in RTF strips, except those of the CTF1 parcel. This exception could be caused due to the response of the wheat crop to excessive amounts of water; on the CTF1 plot, lower values of the maximum yield value and the difference between the maximum and minimum were also found for yield data. The same situation occurred in 2019, also with wheat stands. 
The year 2014 was rich in rainfall with a regular amount of each month during the main growing season (Figure 4). This was reflected in lower mean and median relative yields and NDVI values in the CTF plots than in the RTF strips. CTF areas showed higher standard deviation and lower maximum values than RTF areas. This year, which was rich in rainfall, could have led to excessive water accumulation in this relatively moist plot and a consequent reduction in yield. Likewise, the variety is only moderately resistant to powdery mildew, wheat rust and chaff rust.

In 2016, precipitation had an uneven distribution, with April being relatively dry but significant rainfalls in May and June. CTF areas had a relative higher yield and NDVI mean and higher standard deviation than RTF, which corresponds to the distribution of precipitation during the main growing season. The tillering in April was affected by drought, which showed higher variability in CTF areas as a result. However, the higher mean values of NDVI in CTF plots corresponded to the good condition of the stand on the day of scanning. The variety Hyfi has a very high tolerance against drought and lodging, a moderately high resistant to all common diseases and high ability for tillering, which was reflected in high resulting yield. Georgi et al., 2017 [49] mention that only satellite images of selected vegetation stages should be used to model yield parameters. During the early phenological stages, basic formulas for yield estimation can already be formed, and they reflect spatial differences in the distribution of water and nutrients in the soil. These differences are usually noticeable in satellite images. However, in our study, satellite images from later phenological phases (from heading to development of grains phase) were used, which is consistent with Vallentin et al. (2020) [50], who used a research methodology based on combining soil information, relief structures and multi-temporal satellite data (NDVI) for modeling the zone of wheat field. After the milk grain growth phase, when vitality decreases and the crop matures [51], the information from the satellite images is no longer relevant and usually does not correlate with the yield information [50].

The stand of winter barley, of the variety Wintmalt with a high tillering ability, in year 2017, was affected by higher rainfall in April during the growth phase of tillering and a significant drought in May and June. This was reflected in CTF plots with significantly higher yields and NDVI mean and median values, and on the contrary, a lower standard deviation than RTF plots. This is related to the lowest relative values of the maximum for yield and NDVI and the difference between the maximum and yield. CTF areas showed lower values than the RTF strips. As was described in Knoblauch et al. (2017) study [52], yield is the result of crop growth throughout the growing season and is a response to meteorological conditions in critical growth stages.

Compared to the previous year, the course of total precipitation in 2019 was the opposite-April was very dry, but in May and June there was significant precipitation. Probably due to the lack of water in the growth stage of tillering, the relative mean and median yield values were higher for CTF plots. Although the winter wheat variety RGT Reform has a high ability of tillering, it also has a moderate drought tolerance. The mean and median NDVI values showed balanced values for both CTF and RTF plots in that time period due to high precipitation totals in June. The NDVI image was taken on June 12 from Sentinel 2 during the flowering growth stage. CTF areas had a lower standard deviation and difference between the maximum and minimum yield than the RTF strips. Liu et al. (2022) [53] focused on combinations of soil compaction, crop growth and yield factors of spring wheat in contrast to weather impact. The two-year experiment showed the importance of water availability during crop growth, and more precisely, they showed that during drier seasons soil with higher bulk density and higher moisture content can bring higher crop yields in mean values than soil with low bulk density and moisture content for all evaluated varieties. On the other hand, seasons with higher precipitation in combination with high bulk density and low moisture content showed lower crop yield in mean values for the varieties Alderon, Dala, Diskett, Quarna and Rohan, and variants with low bulk density and high moisture content were found to have higher average yields by Bjarne, Boett, Dacke and Happy varieties. This means that not only does the influence of weather 
and soil conditions affect crop yields, but overall combinations, including the selected variety, have an impact on yields as well. Another study by Tari (2016) [54] stated that wheat is sensitive to the water access, and lower water supplies may result in lower yields. This is in agreement with a study by Chyba (2013) [55] where winter wheat (Ludwig) had lower yields during dry season (mainly in crop growth stage BBCH 70-89) in the case of the non-compacted variant (CTF), while the compacted variant (random traffic) had slightly higher yields. This was explained by the soil water potential (SWP); while non-compacted soil was able to hold the water level for several days, compacted soil maintained this level by more than twice as long. This means that in the case of non-compacted soil, there was a rapid outflow or evaporation of water. In contrast, the water is better retained in the upper layers of the soil profile in the case of compacted soil. Similar results were achieved by Alakukku and Elonen (1995) [56] who performed an experiment with non-compacted soil, once and twice passed over soil by tractor with a trailer. The results from the dry years, especially in June (29-74\% lower than average precipitation), showed an increase in the yields of spring wheat in the case of land once-trafficked soil and a further greater increase in yields in the case of soil trafficked four times.

Precipitation was very unevenly distributed during the year 2021; April and June were very dry, while May and July were very much above average in precipitation. This unbalanced precipitation led to a very uneven relative yield in both CTF and RTF plots. Relative mean yield values were significantly low in the areas CTF1 and CTF2. On the contrary, CTF3 and CTF4 showed higher averages than RTF strips. These relative yield values are in line with the TWI values, i.e., places with a higher value of TWI had a higher relative yield and vice versa. This was probably due to a very dry June, when the lack of precipitation caused an uneven development of spikes and grain across the whole field. It is in line with the relative NDVI values. Both standard deviation yield and NDVI were lower in CTF than in RTF areas.

Yield and NDVI frequency maps showed a significant difference, where FM NDVI reached the maximum value of about $110 \%$, and FM Yield reached about $120 \%$ of the maximum yield (see Table 4). The CTF1 and CTF2 areas reached the lowest values. This corresponded to the lowest mean value of TWI, as in these parts of the field a lower tendency of water accumulation was found. The lower yield in these parts was very pronounced in dry years, e.g., in 2017 (significantly lower max yield value). Compared to individual years, CTF1 and CTF2 are more prone to fluctuations in both yield and NDVI values. Problems with plant growth and spike development were usually most pronounced here. On the other hand, yields were the most stable here (smallest standard deviation). In contrast, the CTF3 and CTF4 areas had a high yield potential. CTF3 especially, with a lower TWI (water accumulation) value, had the highest yield potential, but for cereals only. As evaluation of individual years showed that an excess of water tends to reduce the yield in the CTF areas. On the contrary, in RTF strips with increasing water availability (with increasing TWI value) the values of FM NDVI and yield and their standard deviation also increased, but not to the maximum level.

The results of our study are in agreement with the results of the research of Gili et al. (2017) [57] and Jelínek et al. (2020) [30], which concluded that the determination of management zones depends not only on the objectives of planting and the main yield limiting factors, but also on the agroecological conditions of the site. Agroecological conditions also include the water distribution on the field, which can be expressed quite accurately based on different models (D8 or MFD8 algorithm, TWI) calculated from DEM (Kumhálová et al., 2014 [30], Jenson and Domingue 1988 [58]; Quinn et al., 1991 [59]). However, the question still remains of how much available water the plants can use depending on the different chemical or physical properties of the soil. The combination of all these agroecological variables related to site characteristics and meteorological conditions can lead to differences in productivity between zones with different types of tillage in a given growing season. Differences in tillage and field management may subsequently also show other spectral properties of the crop canopy. Our results also show that it is also 
crucial to select a variety that will be able to thrive on soil with specific characteristics. This conclusion is in agreement with the research of Balážová et al. (2021) [60]. They found that the Khorasan wheat variety had higher average yields in soil with a higher bulk density; conversely, the Kabot variety showed the exact opposite result. The results depended on the total precipitation during the main growth stages.

From the above detailed comparison of the development and yields of cultivated cereals in a monitored field, the following can be summarized. In 2009, CTF areas showed better yields than RTF strips, probably mainly due to insufficient precipitation in April and May. In the rainy year of 2011 with sufficient precipitation in May and June, yields were better in RTF strips, but only by app. 3.9\%. In 2014, with sufficient and regular total precipitation, RTF strips again performed better. The difference in relative yield was $2.7 \%$ in favor of RTF strips. In the next three monitored years, when the weather was dry in April $(2016,2019)$ or in May and June (2017), the CTF areas always performed better. Better performance of field management in dry conditions might be the result of avoiding compaction and conservation tillage [61]. In terms of the weather, the year 2021 was very unfavorable for the cultivation of cereals, as evidenced by the lowest observed yields. This year, probably due to heavy rainfall in May, RTF strips performed better again. However, the yield was only about 3.4\% lower in CTF areas than in RTF strips. In four of the seven years monitored, CTF technology therefore resulted better performances, especially in the case of drier weather in April and May.

\section{Conclusions}

Based on a comparison of the field farmed under CTF technology with conventional (random) traffic management over years with different courses of precipitation in the growing season of cereals and using satellite imagery with the support of yield maps, it is possible to conclude following.

CTF technology applied with conservation tillage is advantageous in dry years. In the drier years, we always recorded a higher average yield in the areas cultivated by CTF technology than in the areas cultivated by conventional RTF technology. In the case of years with wetter weather, CTF technology showed slightly worse results than RTF (only up to $4 \%$ ) than what was expected mainly due to the conversion from intensive tillage to conservation tillage (in 2009). Based on the described experiments, it can be stated that over the years, CTF technology has stabilized yields and given them potential for growth in drier years. It can therefore be stated that the scientific hypothesis about the benefits of CTF technology for the period of climate change has been confirmed.

Nevertheless, average yields calculated from yield frequency maps were lower for CTF plots than those calculated from NDVI frequency maps. This is because NDVI can only show the potential of the state, which can be achieved under optimal conditions in the growth stages before maturity. However, the yield is influenced by many factors and variety adaptation to the site properties, and the conditions in the growth phases before maturity are only occasionally optimal.

Based on the results we obtained, CTF technology can be recommended in conditions with more extreme weather fluctuations, or, in other words, in conditions of climate change.

Author Contributions: Conceptualization-V.R., J.K.; methodology-V.R., M.M., J.G.; softwareJ.K., J.C.; validation-J.K.; formal analysis-J.K. and J.C.; investigation-J.K.; resources-M.M., J.G. and M.B.; data curation-M.M., J.G.; writing-original draft preparation-J.K., F.K., M.M. and V.R. writing-review and editing-J.K., F.K., J.G. and M.M.; visualization-V.R., M.M.; supervision—V.R. and M.M. All authors have read and agreed to the published version of the manuscript.

Funding: This publication is the result of the project: "Scientific support of climate change adaptation in agriculture and mitigation of soil degradation" (ITMS2014+ 313011W580) supported by the Integrated Infrastructure Operational Programme funded by the ERDF. This publication was supported by the Operational Programme Integrated Infrastructure within the project: Sustainable smart farming systems taking into account the future challenges 313011 W112, cofinanced by the European Regional Development Fund. 
Institutional Review Board Statement: Not applicable.

Informed Consent Statement: Not applicable.

Data Availability Statement: Not applicable.

Acknowledgments: The authors are grateful to the staff at the University Farm in Kolinany, Slovakia, for their technical and operational support in conducting this research. The authors would like to thank Richard John Godwin and Tim Chamen for the help with the CTF experiment layout.

Conflicts of Interest: The authors declare no conflict of interest.

\section{References}

1. Statista. Worldwide Production of Grain in 2020/21 by Type; FAO; US Department of Agriculture; Statista Inc.: New York, NY, USA, 2021. Available online: https:/ / www.statista.com/statistics/263977/world-grain-production-by-type (accessed on 30 September 2021).

2. STATdat. Yiel of Agricultural Crops in Slovak Republic. Statistical Office of Slovak Republic. 2021. Available online: http:/ / statdat.statistics.sk/cognosext/cgi-bin/cognos.cgi?b_action=cognosViewer\&ui.action=run\&ui.object=storeID(\%22iC6 F7C81363CE41909892944F24E77E36\%22)\&ui.name=\%c3\%9aroda\%20po\%c4\%benohospod\%c3\%a1rskych\%20plod\%c3\%adn\%2 0\%5bpl2003rs \%5d\&run.outputFormat=\&run.prompt=true\&cv.header=false\&ui.backURL=\%2fcognosext $\% 2 \mathrm{fcps} 4 \% 2 \mathrm{fportlets} \%$ $2 \mathrm{fcommon} \% 2 \mathrm{fclose} . \mathrm{html}$ (accessed on 30 September 2021).

3. Voltr, V.; Wollnerová, J.; Fuksa, P.; Hruška, M. Influence of Tillage on the Production Inputs, Outputs, Soil Compaction and GHG Emissions. Agriculture 2021, 11, 456. [CrossRef]

4. Antille, D.L.; Bennett, J.M.L.; Jensen, T.A. Soil compaction and controlled traffic considerations in Australian cotton-farming systems. Crop Pasture Sci. 2016, 67, 1-28. [CrossRef]

5. Keller, T.; Sandin, M.; Colombi, T.; Horn, R.; Or, D. Historical increase in agricultural machinery weights enhanced soil stress levels and adversely affected soil functioning. Soil Tillage Res. 2019, 194, 104293. [CrossRef]

6. Stettler, M. Boden unter Druck durch Landmaschinen: Immer grösser, immer schneller, immer besser? Thurgauer Bauer 2018, 8 , $20-22$.

7. Alakukku, L. Subsoil compaction due to wheel traffic. Agric. Food Sci. 1999, 8, 333-351. [CrossRef]

8. McHugh, A.D.; Tullberg, J.N.; Freebairn, D.M. Controlled traffic farming restores soil structure. Soil Tillage Res. 2009, 104, 164-172. [CrossRef]

9. Bluett, C.; Tullberg, J.N.; McPhee, J.E.; Antille, D.L. Soil and Tillage Research: Why still focus on soil compaction? Soil Tillage Res. 2019, 194, 104282. [CrossRef]

10. Antille, D.L.; Peets, S.; Galambošová, J.; Botta, G.F.; Rataj, V.; Macák, M.; Tullberg, J.N.; Chamen, W.C.T.; White, D.R.; Misiewicz, P.A.; et al. Review: Soil compaction and controlled traffic farming in arable and grass cropping systems. Agron. Res. 2019, 17, 653-682. [CrossRef]

11. Tullberg, J.; Yule, D.F.; Neale, T.; Chapman, W. Controlled traffic: A matter for science or practice? In Proceedings of the 17th Triennial Conference of the International Soil Tillage Research Organisation, Kiel, Germany, 28 August-23 September 2006; pp. 364-366.

12. Isbister, B.; Blackwell, P.; Riethmuller, G.; Davies, S.; Whitlock, A.; Neale, T. Controlled Traffic Farming Technical Manual; Department of Agriculture and Food: Kensington, Australia, 2013; 78p, ISBN 978-0-9923323-0. Available online: https://www.nacc.com.au/ wp-content/uploads/2015/05/NACC_Controlled_Traffic_Farming_Technical_Manual.pdf (accessed on 18 November 2021).

13. Chamen, W.C.T. The Effects of Low and Controlled Traffic Systems on Soil Physical Properties, Yields and the Profitability of Cereal Crops on a Range of Soil Types. Ph.D. Thesis, Cranfield University, Cranfield, UK, 2011.

14. Kumhála, F.; Gutu, D.; Hůla, J.; Chyba, J.; Kovaříček, P.; Kroulík, M.; Kvíz, Z.; Mašek, J.; Vlášková, M. Controlled traffic farming technology. In Certificated Methodology; Czech University of Life Sciences: Prague, Czech Republic, 2013; p. 42, ISBN 978-80-213-2425-1.

15. Galambošová, J.; Macák, M.; Rataj, V.; Antille, D.L.; Godwin, R.J.; Chamen, W.C.T.; Žitňák, M.; Vitázková, B.; Ďud'ák, J.; Chlpík, J. Field evaluation of controlled traffic farming in central Europe using commercially available machinery. Trans. ASABE 2017, 60, 657-669. [CrossRef]

16. Latsch, A.; Anken, T. Soil and crop responses to a "light" version of Controlled Traffic Farming in Switzerland. Soil Tillage Res. 2019, 194, 104310. [CrossRef]

17. Lemaire, G.; Franzluebbers, A.; de Faccio Carvalho, P.C.; Dedieu, B. Integrated crop-livestock systems: Strategies to achieve synergy between agricultural production and environmental quality. Agric. Ecosyst. Environ. 2014, 190, 4-8. [CrossRef]

18. Antille, D.L.; Chamen, W.C.T.; Tullberg, J.N.; Lal, R. The potential of controlled traffic farming to mitigate greenhouse gas emissions and enhance carbon sequestration in arable land: A critical review. Trans. ASABE 2015, 58, 707-731. [CrossRef]

19. Galambošová, J.; Macák, M.; Rataj, V.; Godwin, R.J.; Žitňák, M.; Vitázková, B.; Ďud'ák, J.; Chamen, W.C.T. Yield performance of controlled traffic farming permanent tramlines. In Proceedings of the ASABE and CSBE/SCGAB Annual International Meeting, Montreal, QC, Canada, 13-16 July 2014. Paper Number 142005820. 
20. Chamen, W.C.T.; Moxey, A.P.; Towers, W.; Balana, B.; Hallett, P.D. Mitigating arable soil compaction: A review and analysis of arable cost and benefit data. Soil Tillage Res. 2015, 146, 10-25. [CrossRef]

21. Schjønning, P.; Lamandé, M.; Munkholm, L.J.; Lyngvig, H.S.; Nielsen, J.A. Soil precompression stress, penetration resistance and crop yields in relation to differently trafficked, temperate-region sandy loam soils. Soil Tillage Res. 2016, 163, 298-308. [CrossRef]

22. IPCC. Summary for policymakers. In Climate Change 2013: The Physical Science Basis. Contribution of Working Group I to the Fifth Assessment Report of the Intergovernmental Panel on Climate Change; Cambridge University Press: Cambridge, UK, 2014.

23. Du, K.; Li, F.; Qiao, Y.; Leng, P.; Li, Z.; Ge, J.; Yang, G. Influence of no-tillage and precipitation pulse on continuous soil respiration of summer maize affected by soil water in the North China Plain. Sci. Total Environ. 2020, 766, 144384. [CrossRef]

24. Li, X.; Wei, B.; Xu, X.; Zhou, J. Effect of Deep Vertical Rotary Tillage on Soil Properties and Sugarcane Biomass in Rainfed Dry-Land Regions of Southern China. Sustainability 2020, 12, 10199. [CrossRef]

25. Hůla, J.; Procházková, B. Minimalization of Soil Tillage (Minimalizace Zpracování Půdy); ProfiPress: Czech Republic, Prague, 2008; ISBN 978-80-86726-28-1. (In Czech)

26. Veloso, A.; Mermoz, S.; Bouvet, A.; Le Toan, T.; Planells, M.; Dejoux, J.-F.; Ceschia, E. Understanding the temporal behavior of crops using Sentinel-1 and Sentinel-2-like data for agricultural applications. Remote Sens. Environ. 2017, 199, 415-426. [CrossRef]

27. Chauhan, S.; Darvishzadeh, R.; Lu, Y.; Boschetti, M.; Nelson, A. Understanding wheat lodging using multi-temporal Sentinel-1 and Sentinel-2 data. Remote Sens. Environ. 2020, 243, 111804. [CrossRef]

28. Zhang, Y.; Migliavacca, M.; Penuelas, J.; Ju, W. Advances in hyperspectral remote sensing of vegetation traits and functions. Remote Sens. Environ. 2021, 252, 112121. [CrossRef]

29. Landsat Satellite Missions. Available online: https://www.usgs.gov/core-science-systems/nli/landsat/landsat-satellite-missio ns?qt-science_support_page_related_con=0\#qt-science_support_page_related_con (accessed on 10 November 2021).

30. Jelínek, Z.; Kumhálová, J.; Chyba, J.; Wohlmuthová, M.; Madaras, M.; Kumhála, F. Landsat and Sentinel-2 images as a tool for the effective estimation of winter and spring cultivar growth and yield prediction in the Czech Republic. Int. Agrophys. 2020, 34, 391-406. [CrossRef]

31. Kumhálová, J.; Zemek, F.; Novák, P.; Brovkina, O.; Mayerová, M. Use of Landsat images for yield evaluation within a small plot. Plant Soil Environ. 2014, 60, 501-506. [CrossRef]

32. Atzberger, C. Advances in remote sensing of agriculture: Context description, existing operational monitoring systems and major information needs. Remote Sens. 2013, 5, 949-981. [CrossRef]

33. Badr, G.; Hoogenboom, G.; Davenport, J.; Smithyman, J. Estimating growing season length using vegetation indices based on remote sensing: A case study for vineyards in Washington State. Trans. ASABE 2015, 58, 551-564. [CrossRef]

34. Jamali, S.; Jönsson, P.; Eklundha, L.; Ardö, J.; Seaquist, J. Detecting changes in vegetation trends using time series segmentation. Remote Sens. Environ. 2015, 156, 182-195. [CrossRef]

35. Gao, B. NDWI-A normalized difference water index for remote sensing of vegetation liquid water from space. Remote Sens. Environ. 1996, 58, 257-266. [CrossRef]

36. Džatko, M.; Sobocká, J.; Granec, M.; Bezák, P. Handbook for Using Maps of Soil-Environmental Units. Innovative Handbook for Agricultural Land Evaluation of Slovakia (Príručka pre Používanie Máp Pôdno-Ekologických Jednotiek. Inovovaná Príručka pre Bonitáciu A Hodnotenie Pol'nohospodárskych Pôd); Soil Science and Conservation Research Institute: Bratislava, Slovakia, 2009; p. 102, ISBN 978-80-89128-55-6. Available online: http://www.podnemapy.sk/portal/verejnost/bpej/prirucka_BPEJ.pdf (accessed on 20 September 2021).

37. Kumhálová, J.; Kumhála, F.; Novák, P.; Matějková, Š. Airborne laser scanning data as a source of field topographical characteristics. Plant Soil Environ. 2013, 59, 423-431. [CrossRef]

38. Kumhálová, J. Inference of topographical characteristics for precision agriculture. Geografie. 2014, 119, 161-178. [CrossRef]

39. Chamen, W.C.T. Controlled traffic farming. In Literature Review and Appraisal of Potential Use in the U.K.; HGCA Research Review No. 59; Agriculture and Horticulture Development Board: Kenilworth, UK, 2006. Available online: https:// citeseerx.ist.psu.edu/ viewdoc/download?doi=10.1.1.563.109\&rep=rep1\&type=pdf (accessed on 15 September 2021).

40. Kroulík, M.; Kumhála, F.; Hůla, J.; Honzík, I. The evaluation of agricultural machines field trafficking intensity for different soil tillage technologies. Soil Tillage Res. 2009, 105, 171-175. [CrossRef]

41. Chamen, W.C.T.; Longstaff, D.J. Traffic and tillage effects on soil conditions and crop growth on a swelling clay soil. Soil Use Manag. 1995, 11, 168-176. [CrossRef]

42. SHMÚ. Climate normals of atmospheric rain fall for period 1981-2010 in Slovakia. In Slovak Hydrometeorological Institute, National Climatologic Program-Roll 15; Ministry of environment of Slovak Republic: Bratislava, Slovakia, 2009; ISBN 978-80-99929-04-4.

43. ENVI 5.6.1 (API Version 3.7); Harris Geospatial Solution, Inc.: Broomfield, CO, USA, 2021.

44. SNAP 8.0.7 Desktop; Open-Source SW; ESA-European Space Agency ESA: Paris, France, 2021. Available online: https://step.esa.i $\mathrm{nt} / \mathrm{main} /$ download/snap-download/ (accessed on 19 October 2020).

45. ArcGIS Pro 2.8.3; GIS SW; ESRI-Environmental Systems Research Institute, Inc.: Redlands, CA, USA, 2021.

46. Kumhálová, J.; Kumhála, F.; Kroulík, M.; Matějková, Š. The impact of topography on soil properties and yield and the effects of weather conditions. Precis. Agric. 2011, 12, 813-830. [CrossRef]

47. Kuznetsova, I.V.; Utkaeva, V.F.; Bondarev, A.G. Assessment of Changes in the Physical Properties of Plowed Loamy SoddyPodzolic Soils in the Nonchernozemic Zone of European Russia under the Impact of Anthropogenic Loads. Eurasian Soil Science 2009, 42, 137-146. [CrossRef] 
48. Lipiec, J.; Medvedev, V.V.; Birkas, M.; Dumitru, E.; Lyndina, T.E.; Rousseva, S.; Fulajtár, E. Effect of soil compaction on root growth and crop yield in Central and Eastern Europe. Int. Agrophysics 2003, 17, 61-69.

49. Georgi, C.; Spengler, D.; Itzerott, S.; Kleinschmit, B. Automatic delineation algorithm for site-specifc management zones based on satellite remote sensing data. Precis. Agric. 2017, 19, 684-707. [CrossRef]

50. Vallentin, C.; Dobers, E.S.; Itzerott, S.; Kleinschmit, B.; Spengler, D. Delineation of management zones with spatial data fusion and belief theory. Precis. Agric. 2020, 21, 802-830. [CrossRef]

51. Geisler, G. Plant production (Pfanzenbau); Verlag Paul Parey: Berlin/Hamburg, Germany, 1988; p. 530, ISBN 3-489-61510-7. [CrossRef]

52. Knoblauch, C.; Watson, C.; Berendonk, C.; Becker, R.; Wrage-Mönnig, N.; Wichern, F. Relationship between remote sensing data, plant biomass and soil nitrogen dynamics in intensively managed grasslands under controlled conditions. Sensors $\mathbf{2 0 1 7}, \mathbf{1 7}, \mathbf{1 4 8 3}$. [CrossRef] [PubMed]

53. Liu, H.; Colombi, T.; Jäck, O.; Keller, T.; Weih, M. Effects of soil compaction on grain yield of wheat depend on weather conditions Sci. Total Environ. 2022, 807, 150763. Available online: https://www.sciencedirect.com/science/article/pii/S0048969721058411 (accessed on 19 October 2020). [CrossRef]

54. Tari, A.F. The effects of different deficit irrigation strategies on yield, quality, and water-use efficiencies of wheat under semi-arid conditions. Agric. Water Manag. 2016, 167, 1-10. [CrossRef]

55. Chyba, J. Influence of Controlled Traffic Technology of Agricultural Machinery on Soil Physical Properties and Crop Yields (Vliv Technologie řízeného Pohybu Strojů po Pozemcích na Fyzikální Vlastnosti Půdy a Výnosy Plodin). Ph.D. Thesis, Czech University of Life Sciences, Prague, Czech Republic, 2013. (In Czech)

56. Alakukku, L.; Elonen, P. Long-term effects of a single compaction by heavy field traffic on yield and nitrogen uptake of annual crops. Soil Tillage Res. 1995, 36, 141-152. [CrossRef]

57. Gili, A.; Álvarez, C.; Bagnato, R.; Noellemeyer, E. Comparison of three methods for delineating management zones for site-specific crop management. Comput. Electron. Agric. 2017, 139, 213-223. [CrossRef]

58. Jenson, S.K.; Domingue, J.O. Extracting topographic structure from digital elevation data for geographic information system analysis. Photogramm. Eng. Remote Sens. 1988, 54, 1593-1600.

59. Quinn, P.F.; Beven, K.; Chevallier, P.; Planchon, O. The prediction of hillslope flow paths for distributed hydrological modeling using digital terrain models. Hydrol. Processes 1991, 5, 59-79. [CrossRef]

60. Balážová, K.; Chyba, J.; Kumhálová, J.; Mašek, J.; Petrásek, S. Monitoring of Khorasan (Triticum turgidum ssp. Turanicum) and Modern Kabot Spring Wheat (Triticum aestivum) Varieties by UAV and Sensor Technologies under Different Soil Tillage. Agronomy 2021, 11, 1348. [CrossRef]

61. Busari, M.A.; Kukal, S.S.; Kaur, A.; Bhatt, R.; Dulazi, A.A. Conservation tillage impacts on soil, crop and the environment. Int. Soil Water Conserv. Res. 2015, 3, 119-129. [CrossRef] 